U. D. C. $614.8: 662.75$

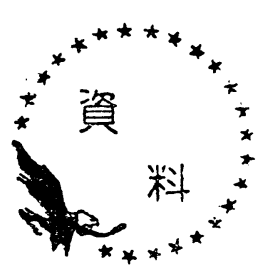

最近の都市ガス工業は, そのガス源を石油系原料 (原油, ナフサなど) に求むる傾向が，ますますさか んとなり 37 年度中には原油を原料とするもの 2 基, ナフサを原料とするもの 55 基が建設されたが，本年 に入り 4 月末現在で原油のガス化装置 2 基, ナフサの ガス化装置 28 基が建設中である。

今後とも多くの事業者が陸続と採用されることにな ると思らが，これらの原料は保安上きわめて危険であ り, 輸送, 貯蔵などへの取扱いには適切細心な配慮を 必要とすることは周知のとおりであり，この見地から 日本瓦斯協会においても，36 年 3 月に“原油，ナフ サ，L P G 取扱基準”を刊行して，大方の指針として いるので本稿においては，法律の規定などを削き，こ れだけは是非とも心得ておきたい。卑近な注意を述へ てご参考に供したい。

\section{I . 物質の危険性}

1. 蒸気圧について

ガソリンの性状中，蒸気圧として試験され規制され ているが，この性質により各種の作業や貯蔵状態から 発生した石油ガスが排出され, 滞留流動して各種の引 火着火の事態を惹起して, 火災爆発の原因となる。

火災予防上，この性質に対しては火気使用の規制を 㛜重にすることはもちろんであるが，石油ガス発生源 を隔離したり，その危険予防のための設備を充分点 検, 整備しておくこと以外に最も重要なことは，気象 条件と移動する着火源，および作業行動から生ずる火 花発生の防止に注意しなければならない。

2. 爆発について

ガソリンの萜気が約 $1.4 \sim 7.6 \mathrm{Vol} \%$ の範囲で空気 と混合すると爆発性混合ガスとなる。この混合範囲で は, 燃焼速度が非常に速く, 容器内から空間に至る部 分まで，広範な環境下で起り得る。しかも着火はわず かな火花でも可能である。

石油ガスの爆発事故は，しばしば大惨事を引き起す が，蒸留などのごとく特別熱した場合よりも揮発性に よつて発生した原因による場合が非常に多い。
日本瓦斯協会 田中 三 郎

ガソリンは非電導性であるので, 流動, '沪過, 滴下, 噴霧などの際に帯電し，放電火花によつて引火または 爆発の危険がある。

したがつて静電気などの放電発生原因の除去および 作業上の火花発生を防止することである。

3. 自然着火温度がある

特別点火しなくとも $250^{\circ} \mathrm{C} \sim 300^{\circ} \mathrm{C}$ 程度で自然に着 火する性質がある。

4. 石油ガスの比重が重い

ガソリンガスの比重は空気の 3.5 倍で, 低い個所に 流れ室内や風速の弱い場合停滞する所以である。

$40 \mathrm{~m}, 50 \mathrm{~m}$ の遠方の火から引火した例が多い。また タンクの掃除の場合, マンホールを開放すると, 下部 マンホールから激しい速度でガスが排出され, 上部か ら空気を吸大して置換する。

某油槽所での火災事故はこの例である。風下方向の 火気に対して充分注意する必要がある。

前述のごとく気温, 気圧に対してガソリンガスの発 生, 温度と静電気, 風速と石油ガス濃度, というょう に火災予防と安全に対して重大な関係があるので, 常 識上の火気のみならず潜在火気，すなわち火花を発す る作業行動, 機器に至るまで火気と考えなければなら ないとともに検知器を使用して, ガソリンベイパーの 検知を行なら必要がある。

\section{II. 取扱上の注意}

1）輸送小量で災害の発生するおそれのない時以 外，ナフサと他のものを混載してはならない。

2) ドラムは日光の直射をらけないように適当なも ので被覆すること。

3）ナフサを入れたローリー車やドラムを積み降し する場所では，契煙はむとより，マッチやライタ 一を携帯したり，また鉄鋲のついている靴をはい てはならない。

4) 積み降し場所の電気配線, 器具拉よび照明装置 は防爆構造のものにしておくこと。

5）作業にあたつては，高らかじめ手摺を握るなど 
して人体の静電気を放電しておくこと。

6）積み降し場所では，衝撃火花を出さない安全工 具を使用し，また衝撃を与えないようにするこ と。

7）ドラムおよびタンク車の中味を出し入れする前 に, これ等の容器, 受器, 取出しパイプ, ポン プ,タンク車などは適当な接地線で接地して静電 荷起除くこと。

8）タンク車の中味を取り出す作業中は，エンジン を必ず止めておくこと。また決して始動させない こと。

9）ドラムの中味をあける時には，手動ポンプまた は防爆型の電動ポンプを使う方が安全である。

10）管内流速は $1 \mathrm{~m} / \mathrm{sec}$ 以下とすること。

11）電池で操作するフォークリフトラックは，火焰 防止型のものでないと危険である。

12）タンク車に積み降しするときは，「停止タンク 車荷役作業中」の立札を立てること。

13）荷役位置は，原則として，常時火気使用場所よ り $40 \mathrm{~m}$ 以上の巨離をとるのが望ましい。

14) ナイロンその他の化学瀻維の衣類は摩擦によつ て帯電し, 放電火花によりガソリン蒸気に引火す るおそれがあるから，着用しない方がよい。

15）火災, 停電, 機械の故障の非常借置の方法を熹 知さしておくこと。

16）電気設備の修理は，みだりに施行してはならな い。必ず危険のない状況を確めて, 専問係員に依 頼すること。

17）運転中は電流が規定より超過しないよう，また 各ベアリング，モーターの発熱状況を注意するこ と。

18）雷が近づいたら，パッチ，カバーなどは正しく 閉じて待期すること。

19）業者の運転手は登録せしめ, 登録外の連転手に よる構内進入を認めない方針とすること。初めて 登録された運転手に対しては，構内の危険作業と 火気制限，運行制限を徹底させること。

2. 貯蔵上の注意

1) ナフサを指定量 (100l) 以上咛蔵する場合に は，消防法により許可を受け政令にしたがつて種 々の施設をしなければならない。

2)これらの貯蔵施設の敷地の大口附近の外部から みやすいとこ，つぎの揭示をすること。

白地に黒で「危険物貯蔵所」「貯蔵する最大数 量」「危険物取扱主任者名」を記した札，ならび
に赤地に白で「火気厳禁」と書いた札，マッチ， ライター, 裸火, 鎔接器具および発火器具類は, 施設の長の許可がなければ所内に持込みを禁じ, また猰煙は所内指定の場所以外では禁止する旨を 記した札を掲げる。

3）地上タンクの周囲は, コンクリートなどの防油 堤で囲み, 万一タンクが破損してナフサが流出し たときにも，拡大することを防ぐこと。

4）地上タンクの支持物は鉄筋コンクリートのよう な耐火構造とし，裸の鉄骨は火桨時に接壤するお それがあるから必ずコンクリートで巻くこと。

5）空地の中は, $1 \mathrm{k} l$ 以下の場合 $3 \mathrm{~m}$ 以上とし, $1 \mathrm{k} l$ をこえる場合は $5 \mathrm{~m}$ 以上とすること。

6）地上タンクおよび配管はすべて接地すること。 接地抵抗の高い場合には接地を確実にするため に，少なくとも $2 \mathrm{~m}$ 以上の深さに銅製の接地棒， または接地板を埋め，この棒または板とタンクと は銅線で確実に接続し, その接地抵抗は $10 \Omega$ 以 下とすること。

ただし，避雷針を設けない場合，側板の接地抵 抗は $5 \Omega$ 以下にすること。

7）地下タンクは厚さ $3.2 \mathrm{~mm}$ 以上の鋼板で気密に つくり,0.7 kg $/ \mathrm{cm}^{2}$ 以上の水圧試験に耐えるこ 亡。

8）地下タンクは政令にしたがつたコンクリートの タンク室に設け，または政令に定める方法で保護 されて堅固な土台に固定されていること。

9）地下タンクの頂部は少なくとも $60 \mathrm{~cm}$ 以上地盤 面から下にあること。

10）無弁通気管はつけるものとする。作業圧力範囲 はコーンルーフタンクの場合はできるだけ大きく とる。作動差圧力 $100 \mathrm{~mm}$ (水柱) 以下のこと。 取付数は 2 箇以上が望をしい。

通気管の直径は $30 \mathrm{~mm}$ 以上とし, その先端を 水平より下に 45 度以上に曲げて雨水の浸入を防 ぐ構造とし，細目の銅龬などによる引火防止装置 をつけ SUS材質はが望ましい。

金網は定期的に点検し，常に整備を心脚けるこ と。(揮発油は10 ケ月程度で穴があくと考えられ る。

11）注入口はタンク下部につける。上部につける場 合にはサイフホンにならぬよら注意する。

注入に除しては，爆発の危険をさけるため，噴 射流入，衝撃，攪挥などによる静電気の発生を少 なくするよう注意すること。 
12）常に容器内の油面を確め, 内容積の $90 \%$ 以上 に油を入れてはならない。

13）タンクの容量に応じて撒水装置をつけた方がよ い。

撒水能力は, 夏期使用の他にタンク周辺の火災 の場合の泠却用も考慮して計算すること。

14）無風或は微風時におけるタンク周囲のガス濃度 を測定して，その危険対策の要否など充分認識し ておくこと。

15）ガスの滞留しているタンクのマンホール, 検尺 孔などを開放するときは, 風向, 風速などを考慮 して徐々に行なわなければならない。

16) 貯蔵場所の電気機器および配線はすべて防爆構 造とすること。

17）タンク内において爆発性混合物を発生させない ように注意しなければならない。

爆発範团はつぎのと朽りである。

$$
\begin{array}{ll}
\text { ガソリンベイパー } & 1.5 \% \sim 7.6 \% \\
\text { 原油ベイパー } & 1.0 \% \sim 8.0 \%
\end{array}
$$

18）タンクに接近して工事を行なら必要ある場 合 は，ガス嵞知を行なつて危険のないことを確める ほか，タンクえの注油を中止するなどの措置を講 じなければならない。

19）タンク, 配管, ポンプ室などに対し, 自動車, オート 2 輪車の接近を制限すること。

如何なる条件でも $0.1 \%$ 以上の濃度になる範囲 では運行を禁止することが必要である。

20) 避雷設備は, 2.2.6 項に記したように接地抵抗 を $5 \Omega$ 以下にした場合側板を有効な避雷設備とみ なじ別に避雷針は設けないが高さ $20 \mathrm{~m}$ をこえ るものにあつては建築基準法第 33 条によつて避 雷設備が入用となる。

3. タンク掃除する場合の注意

1）下部マンホールの開放は徐々に行なうこと。そ の程度は, 風速, 風向, 附近の火気の有無, ガス 濃度などを検討しつつ行なう。できれば風速の高 、日を選ぶこと。マンホール開放作業には工具㧍 よびその他による火花発生がないよう厳重な注意 が必要である。

なお、マンホールのボルトを緩めたら残油の浸 出の有無を調查して, 残油面がマンホール以下で あることを確認してその後の作業を進めること。

2）マンホールを充分開放したら直ちに残油の有無 を確認すること。残油の多い場合はさらに水攻め 等により吸引する。
3）開放後ガス放出中は，危険範囲を繩張りなどで 明示して，関倸者以外の区域内出入りを禁止する こと。

4）できるだけタンク内作業は，ガス量が $0.1 \%$ 以 下，酸素の濃度は 16 21\% の間であることを確 か内放て実施すること。ガス量が $0.4 \%$ 以上の場合 はタンク内作業は, 例外として禁止すること。

5) ガス量が可検範圈 (0.03\%) 以上の場合はマス ク着用のこと。

6）タンク内に可然性のガスまた注気が残留して いる場合には，電気火花によりガス爆発を起す危 險があるので, 移動灯または懐中電燈は防爆構造 のを使のも用しなければならない。

ま代導線は絶縁良好なものを使用し, 被覆に損 傷のあるものを使用してはならない。

7）最初のタンク底の残油掃除には火花を発する工 具は使用しないこと。タンク内作業はガス中毒等 を考慮して 2 名以上で実施すること。

8）タンク内面掃除は消火栓などを使用して水洗掃 除とし，充分安全にならない限り金物を使用して はならない。

このよらな圧力水で側板の銹やスケールを掃除 すると再びガス濃度が高くなるから注意を要す る。

前述の残油追出しや撹除のために使用する水木 一スは, 予め充分水で浸しておくことが肝要であ る。

また水蒸気をタンク内に噴出せしめる際には静 電気の発生の恐れがあるから, 水蒸気は低圧のも のをできるだけ低速で導入し，蒸気パイプはタン クと導線で速結して接地すること。

9）密閉すると銹やスケールからガスが発生して濃 度が高くなるから，摔除中はマンホールを夜間で も開放したままがよい。スケールには液体として の揮発油が吸着しているものと考えること。

10）取出したスケールは，放置すると自然発火する 恐れがあるから，適当な位置に穴を掘つて埋没す ること。

11）タンク類の火気使用には予備測定はもちろんの こと，その直前にガスを検知して充分安全である ことを確めなければならない。ガスが可検範围に 検知された場合，そのガスの源泉が何によるもの かを検討確認しな配ければならない。

12）タンクに火気使用を行なう場合は関倸配管に盲 板を入れなければならない。 
13）配管類の修理を行なう場合は在油を全部抜出し てから行ならことを原則とする。

火気使用する場合は水洗を行ない必要な位置に 盲板を入れてから行なうこと。

14）タンク内作業を一時中断した場合には，その間 にガスの漏洩，その他によってタンク内の状態が 変化することがあるから，作業の再開に先立つて 再び必要な検査をやり直して安全を確認しなけれ ばならない。

15）安全な作業環境に適した個人保護具の正しい選 択と使用にはかなり高度の知識を必要とするか ら，監督者は服装，頭部の保護，眼および顔の保 護, 足の保護、呼吸保護具について, よく検討し た上，あらかじめ作業員にこれに関する充分な知 識を与え，さらに訓練を施さなければならない。

4. その他の注意事項

1）引火性液体は爆発性混合ガスを生成する機会が きわめて多いため，ガスまたは蒝気の漏出源が多 く分散している場合には，屋外または開放型の建 家が望ましく，やむを得ず装置を屋内に設ける場 合には有効な全体換気を必要とし，2 個以上の出 大口を退避しやすい位置に設け，屝は外開きにす ること。揮発油の場合, その蒸気は空気より重い から (3.5倍)，換気孔の位置は床と同じくらいの 高さにすること。

またベンチレーターのパイプは床上 $10 \sim 15 \mathrm{~cm}$ まで下げることによつて有効に排出される。

2）揮発油が洩れた場所は通風をよくし，圧縮空気 があれば吹かして蒸気を戸外に追い出す。ガソリ ン濃度を測り，0.05Vol\% 以下になってから空や 屝を閉的る。

ガソリン蒸気の濃度の測定法にはつぎの形式が める。

(1) 干渉屈折式 (口) 接触然焼式 ( 検知管式

3）機械設備の摩擦による発熱あるいは機械的衝撃 による火花も，爆発性混合ガスの点火源によることが ある。たとえばベルトのスリップまたは接触による過 熱, 軸受の過熱などの場合, その温度が混合ガスの発 火点以上であ机ば発火する。また鉄製の装置などを鉄 ハンマーでたたいたり，鉄鋲のある靴をはいてタンク リートの上を歩く場合などの衝撃火花も, 可燃性ガス または蒸気一空気混合ガスを点火する恐れがある。

従つて危険場所では鉄製の工具の使用を避け, バリ ウム銅またはアルミニウムブロンズで作つた安全工具 を使用すべきであり，危険度の高い場所では電導ゴム
底の靴をはくことが望ましい。また機械の動力伝導装 置のすべりの防止および軸受部の注油を厳重に行なつ て摩擦による過熱が起らないようにする必要がある。

\section{III. 静電気による発火危険とその対策}

静電気収塵法 (コットレル法), 静電塗装法, 静電 分離法など工業的に盛んに利用せられている反面, 多 くの事業場において自然に発生し, それが畜積して各 種の障害を与えている場合が少なくない。

静電気障害の主なものはつぎのとおりである。

（1）带電体相互の反発または吸引による工程障害

（2）吸塵または放電火花による品質の低下

（3）畜積電荷の放電火花による爆発性混合ガスの 発火危険

このらぬ放電火花による混合ガスの発火は，その結 果として重大な火災または爆発災害を発生する恐れが ある。したがつてナフサのごとき引火性液体を取扱う 場所では火気使用の禁止, 電気設備の防爆化などと同 様に, 点火源としての静電気の除去についても充分な 対策を䛾ずる必要があるが, どのようにして静電気を 発し,どのようにして放電が起つたかの点について明 確な考察を行なわなければならない。

静電気の発生, 放電, およびこれによる爆発なぞの 現象は，それぞれ相当な原因の結果として起るもので ある。

一般に静電気による爆発はつぎのような 3 つの条件 が重なつた時にのみ起る。

（1）爆発性のガスが存在するとき

（2）静電気が発生して，これが液体または固体中 に畜積され，ガスの中に電場を生じているとき

（3）この電場がガスに点火するに充分な強さの火 花を発生するとき

したがって静電気による火災を防ぐためには，この 3 条件の少なくとも1つを取除けげ事故を防ぐことが できる。

以下, 静電気発生の原理, 対策などについて逐次述 べてゆくことにする。

1. 静電気発生の機構

周知のごとく静電気中不良導体の摩擦, あるいは不 良導体と良導体間の摩擦によつて生ずる。

またこの他にも，微粒子が運動して互いに摩擦を生 ずる場合, 液体が細か、微粒子に分散する場合, ある いは接触していた二つの物体が引離される場合, 液体 が分離して二層に別れる場合なども静電気が発生す る。

ナフサのごとき引火性液体は固有抵抗が高く $10^{12} \sim$ 
$10^{14} \mathrm{ohm}-\mathrm{cm}$ 以上であるので，良好な電気絶縁体と考 えられるから，パイプの中を流動する際にはパイプお よび液体にも静電気が発生する。

動力伝導装置のベルトがプーリーと密着して離れる とき，あるいはベルトがゆるいとき，プーリーとの过 りの摩擦などによつ, 強く帯電する。自動車が走る場 合にも, 空気との摩擦およびタイヤと路面の摩擦によ つて静電気が発生している。

この他すべての物体の運動によつて静電気が発生し ている一方, 非常に発火しやすい可然性ガスまたは引 火性液体が多量に取报われていることを考え合わせれ ば，静電気による火災または爆発の危険は非常に多い といわなければならない。しかし，普通空気中で火花 放電が起きるためには，少なくとも $400 \mathrm{~V}$ 以上の電圧 を必要とするので, これより低電圧の帯電は荷電量が 大きくてもさほじ危険ではない。

\section{2. 帯電体の導電性}

前述で明らかなように, 導体, 絶縁体の別なく接触 する 2 物体間に接触電位差が存在するかぎり, 静電気 の発生そのものは避けられないのであるが，発生した 静電気がすみやかに漏洩または中和してしまうような 条件のもとではもらろん帯電現象は起らない。すなわ ち物体の帯電量清争電気の発生量と漏洩速度との関係 で決まるもので，物体の導電性または接地の良否によ つて帯電の難易に大きな相違がある。

たとえば，ゴムベルトなどは導電性が非常に恶く， 体積固有低抗が $10^{14} \mathrm{ohm}-\mathrm{cm}$ 程度である。このた め, いつたん発生した静電気は容易に漏洩せず, 動力 伝導用のゴムベルトは 10,000 20,000V に帯電した といら記録分ある。

人体の運動による帯電は，ゴム底の靴をはいている 時, または床功電気抵抗の高いリノリウム, 大理石, アスケァルトなどの場合に起こる。これらの物体, 人 体の接地抵抗は $1,000 \mathrm{M} \Omega$ 以上になることがあるとい われ，静電気が畜積され易いことがわかる。

3. 空気の湿度

空気の相対湿度が高いと物体は一般に带電しにくく なる。

静電気が物体内部を通つて逸散する場合であるが， 湿度の高い場所では物体の表面にきわ的て薄い水分の 膜が凝縮し，これに空気中の炭酸ガスが溶解して電離 しているので，この薄膜を伝わつて静電気が漏洩す る。このように大気中の湿度が高く, 空気がある程度 の電導度を持つ場合には，発生した静電気が一部分空 気をとおして逃げるが，冬期のごさく空気の乾燥して

いる場合にはこのような現象が期待されず，また同一 \%の湿度であつても気温の低い時は飽和水分の量が少 ないから，このような場合は静電気の畜積には一層好 都合となるわけである。

65\%以上の湿度があると畜積された静電気は減少す ると考えられているが，それ以下は注意が必要であ る。T石油会社の場合， $6^{\circ} \mathrm{C}$. 湿度 $55 \%$ で事故が発生 している。

\section{4. 石油製品による静電気の発生}

石油製品がパイプの中を流れる摩擦によつて静電気 が発生するということは, 古くから知られており, ま た多くの実験によると, 石油製品の純度が高いと比較 的静電気の発生が少ないが，極く微量の不純物の存在 によつて静電気の発生が促進される。

不純物とは, 製品の酸化物, アスファルテン・スル フホン酸またはナフテン酸の金属塩および水分などで ある。たとえば $1,000 \mathrm{t}$ の石油製品中に $1 \mathrm{~g}$ の不純物 が存在しても著るしい帯電現象を示すことがある。

このような微量の不純物は沪過などの操作によつて は充分に取除くことはできないが，シリカゲルや活性 白土などに吸着させれば，ほとんど取除くことができ る。しかし実際にはこの操作中にこうした物質が混入 することは避けられないから，これによつて静電気の 発生を防ぐことは不可能である。

かように石油製品による静電気は, 油が他の固体ま たはガス体に対して相対的な運動をする時に発生す る。これを第 1 表に示すと下記のごとくなる。

\section{第 1 表 静電気発生の原因}

油が動く場合

1. 固体表面を動く場合 パイプ,タンク内壁,フイ ルター沈泥, タンクの錆

2. 液体表面または液体中 を動く場合

水, 化学薬品

3. ガスの中で霧状の油が 動 $<$ 場合 空気, 炭化水素蒸気

5. 静電気の蓄積と石油製品の比抵抗

石油製品は一般に不良導体である。従つて発生した 静電気は油の中に次第に蓄積されて電圧を増し, 遂に は火花放電を発生することもある。しかし油の電気抵 抗值が比較的低ければ, 発生した静電気は油を通じて 逃げてしまうから安全である。

たとえば通常油がパイプの中を流れることによつて 
生ずる電流は約 1 マイクロアンペア程度であるから, 油を通じて大地に至る間の抵抗が $300 \mathrm{M} \Omega\left(3 \times 10^{8} \Omega\right)$ であれば,この間を電流が流れて生ずる電圧は $300 \mathrm{~V}$ となり,もはや空気中で放電を起こすのに不充分とな る。

石油製品の比抵抗が $10^{11} \Omega \mathrm{cm}$ 以下の場合には, 静 電気の蓄積は問題にならないと考えられている。元来 炭化水素の比抵抗は非常に高いものであるが, 微量の 不純物の混入によつて, その比抵抗が低下寸る。従つ て, 原油柱不純物を多く含むために比較的抵抗が小さ く, 大体 $1 \times 10^{9} \sim 1 \times 10^{11} \Omega \mathrm{cm}$ の範囲にあるから， 静電気の蓄積は少なく, あまり危険はないといわれて いる。

一般に石油製品の比抵抗は大体 $10^{10} \sim 10^{16} \Omega \mathrm{cm}$ の 範因にあるが，同一種類の油でも，その純度のわずか な差によつて非常に異なつた抵抗值を示す。これから みると,すべての石油製品は発生した静電気を伝導さ せるのに不充分な抵抗值を持つていることがわかる。

油の比抵抗による影響は, 比抵抗が $10^{11} \sim 10^{15} \Omega \mathrm{cm}$ の範囲内にあれば静電気を発生しやすく,この範囲外 の油は比較的不活性である。

前述のごとく, 油の中の静電気発生は微量の不純物 が存在することによるもので, これは同時に油の比抵 抗を減ずる。比抵抗の高いことは不純物の少ないこと を示し，したがつて静電気の発生も少ない。逆に比抵 抗の低いことは不純物が比較的多いことを示し，した がつて静電気の発生も増加するが, それよりも伝導に よつて油の中から逃げる静電気が増加するた为放電が 起こらないわけである。

6. 带電防止対策

静電気が点火源となつて火災または爆発災害が起る ことを防止するには，物体の静電気の蓄積量を危険な 火花を発生し得ないまでに制限しなくてはならない。 そのためには，(1) できるだけ静電気の発生を少なく すること，(2) 発生した静電気をすみやかに油漏また は中和せしめる必要がある。

そして, 二つの対策を効果的に実施するには, 発生 理論の理解と実際の帯電状況を正確に知ることが必要 である。

1）静電気の発生制限

二つの物体の一方または両方の電気抵抗が高く, か つ，その両者が接触してのち離れるような機構では， 静電気の帯電を防止することはほとんど不可能であ る。しかし摩擦を少なくすること，速度を少なくする こと，および相互の材質を適当に選定することによつ
て, 静電気の発生はある程度制限される。

2) 摩擦の減少

前述のごとく固体と固体との接触において静電気が 最も多く発生するのは滑り摩擦である。すなわち, 2 つの物体を摩擦させた場合は，それを単に圧着させた 場合に比し桁近くも多く静電気が発生するといわれて いる。

従つて, ベルト・ロールなどの帯電は, スリップを 少なくすることによつて大いに制限できるはずであ る。

3）速度の制限

液体の流動帯電における静電気の発生量は, これら の流体が単位時間内に固体表面に接触面積に比例す る。換言すれば, 単位流量あたりの静電気の発生量は 比接触面積が大きいほど大きく, また単位時間あたり 発生量は流速に 1.75 乘比例するといわれる。したが つて, 石油製品のごとく導伝性液体の流動に伴なう静 電気の発生を制限するには, 比接触面積および流速を できるだけ小さくする必要があり,アメリカで長い間 検討した結果，3呎 $/ \mathrm{sec}(0.91 \mathrm{~m} / \mathrm{sec})$ の速度以下で 西れば安全であると一般に認められている。

この速度は大体 $4 \mathrm{~B}$ では $29 \mathrm{k} l / \mathrm{h}, 3 \mathrm{~B}$ では $17 \mathrm{k} l / \mathrm{h}$, $2 \mathrm{~B}$ では $12 \mathrm{k} l / \mathrm{h}$ 程度である。注意しなければならない ことは, パイプの中の流速を調節するには, タンク入 ロのバルブによらないで必ずポンプの出ロバルブを絞 つて行ならということである。またタンクの上部から 給油する場合, 電圧が高くなるのは, 給油管の筒先か ら油が離れる時であるといらことが実験で明らかにな つている。筒先から油が勢いよくパイプの先端を離れ 空中に噴出すると，たちまち，今まで管中を流れてい る間比較的低圧で, ある程度の量を持つていた静電気 が，今度は量は少なくなるが，電圧が非常涪高電気 に変化するわけである。

ただしこのような転位は, 筒先が液面に没入すると 止むといわれている。従つて, 空間部分が爆発燃焼範 囲のガス状になっていれば，事故となるわけである。 このような場合，筒先や周囲にある物体をすべて確実 にアースするのが最もよい方法である。

また, 静電気が高電位化転位する間を早く終らせる ため注入管を深く下げ底につくようにするのも一方法 である。

4）静電気の蓄積防止

静電気は発生しても, それをすみやかに大地に漏洩 せしめるか, または安全に中和して, 物体内に蓄積さ せなければ，火花放電による発火の危険はなくなる。 
それには次のような方法がある。

(1) 金属部分の接地 接地は最も確実な帯電防止方法であり, 一方絶 縁状態にある金属部分は, 蓄積電荷が一時に放電 してエネルギーの大きい火花を発生するので, 最 も危険な帯電物と考えられる。

従つて, 危険場所では, 帯電に関係あるすべて の金属部分は必ず充分に太、電線を用いて, 水道 管または完全な接地板に確実に接続しておく必要 がある。この場合注意しなければならないのは， 錆などの発生によつて大地から絶縁される場合が あることがある。

またタンクなどを洗滌する場合，スチームの噴 射はかなりの静電気を発生する。従つて, 設備を スチームでパージする前に, その中の物体とホー スの筒先は確実に接地しておかなければならな い。また，ドラム午をスチームで洗條する場合に は，接地した金属製の台の上に置くなどして，こ れを完全にアースしておくことである。

(口) 導伝性の附与

金属のごとき導電体に発生する静電気は接地に よつて完全に除くことができるが，絶縁体の表面 に発生する電荷は，除去することは，困難であ る。従つて, 静電気の発生し易い個所にはできる だけ金属製のものを用いて接地することが望まし く, やむを得ず電気絶縁性の材料を使用するとき にも, その固有抵抗をある限度以下にして電荷の 自然漏洩をはかるべきである。

従来この点で最も問題となるゴムベルト, タイ ヤ, ホースなど, 固有抵抗がきわめて高いため多 くの静電気障害を生じている。しかしこれに多量 のカーボンブラックを混入した導伝性ゴムを使用 すれば，帯電の危険をかなり減少することができ る。たとえばガソリン注入用のゴムホースは，導 伝性ゴム製のホース内壁にらせん状の針金を理め 込み，これを注入用答先の金物に速結して接地す るようにできている。

(৬) 相対湿度の増加

前に述べたように, 空気中の湿度が高いと, 物 体の表面に，わずかであるが，湿度のフイルムを
作るようになる。このフイルムは，気のつかない ほどにわずかなものであつても，表面の伝導性を よくし，電荷の蓄積を防止する。

静電気災害は冬に多いが，冬期に空気中の相対 湿度が低い上に，外界の気温が低いために，低温 の外気が室内に入つて暖められ，一層室内の相対 湿度を低下するものと考えられる。したがつて， 事情の許すかぎり湿度を増すことが带電防止上き わめて有効である。

(そ) その他

静電気は, ガスが泡となつて上昇する際にも， この泡が带電した油を表面まで持ちあげ, 油の表 面層に静電気を蓄積させて, 蒸気相の電場の強さ を増すから，パイプ中にガス体が混入しないよう に注意しなければならない。

以上静電気による災害危険とその対策について概要 を簡単に説明したが従来製油所において原因の不明確 な爆発が起つた場合, 静電気による事故であるという ことが判明している場合にも，これがどのようにして 静電気を発し，どのようにして放電が起つたかという 点になると，あまりはつきりしないままに処理せられ ることがしばしばあつた。

これは一般に静電気現象が比較的その実態のつかみ にくいものと考えられ, ややもすれば明確な対策や考 察が行なわれない傾向があつたためである。しかし最 近静電気に関する研究が各方面において盛んになり， 幾多の業績が発表されつつあるが，これらの問題につ いてなお今後の研究にまつべきことが多く, 静電気の 発生, 放電およびこれによる災害危険性との関係は, それぞれ相当な原因の結果として起こるものであるか ら，現場にそくした方法で検討を行ない，現実的数值 で安全の限界を求めることが必要と考えられる。

\section{文献}

防災指針 7 ベンゼン類

" 15 ガソリン

" 17 タンク内作業

伊東電機(株)静電気による発火危険とその対策

出光技報 静電気による爆発について

安全博物館協会 静電気による災害危険とその対策 日本石油(株)石油の性質と安全 


\title{
Prevention of Disasters Arised from the Use of Naphtha
}

\author{
by Saburo Tanaka \\ (Japan Gas Association)
}

SYNOPSIS:- The vapor pressure, ignition temperature and explosion limit are important factors relating to the dangerous properties of naphtha.

In this report, matters that demand special attention are described to prevent disasters in handling naphtha in transportation, storage and cleaning tanks.

In addition, the ignition by static electricity and its counter-measure are also mentioned.

\section{会費払込みについて}

昭和 38 年度会費未納の方は，下記により至急御払込み下さいますよう，御願い致します。

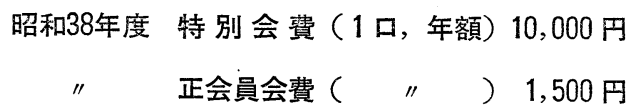

東京都 中央区銀座西 4 の 5

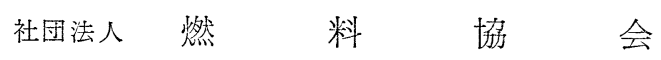

TE L（561）3760 振替口座 東京 55504 